\title{
Analytical Methods for the Determination of the Distribution of Total Petroleum Hydrocarbons in the Water and Sediment of Aquatic Systems: A Review
}

\author{
A. O. Adeniji, ${ }^{1,2}$ O. O. Okoh,, ${ }^{1,2}$ and A. I. Okoh ${ }^{1,3}$ \\ ${ }^{1}$ SAMRC Microbial Water Quality Monitoring Centre, University of Fort Hare, Alice 5700, South Africa \\ ${ }^{2}$ Department of Chemistry, University of Fort Hare, Alice 5700, South Africa \\ ${ }^{3}$ Applied and Environmental Microbiology Research Group, Department of Biochemistry and Microbiology, \\ University of Fort Hare, Alice 5700, South Africa
}

Correspondence should be addressed to A. O. Adeniji; adenijigoke@gmail.com

Received 6 February 2017; Accepted 2 April 2017; Published 16 April 2017

Academic Editor: Ana Moldes

Copyright (C) 2017 A. O. Adeniji et al. This is an open access article distributed under the Creative Commons Attribution License, which permits unrestricted use, distribution, and reproduction in any medium, provided the original work is properly cited.

\begin{abstract}
Several methods of extraction and analytical determination for total petroleum hydrocarbons (TPHCs) in aqueous and solid samples are reviewed. Infrared spectroscopy is one of the efficient methods that are being replaced today pursuant to getting rid of some halogenated solvents classified as ozone-depleting substances. The gravimetric method which uses n-hexane as an extraction solvent for the determination of oil and grease, as well as the nonpolar materials, has become a preferred choice, despite being not suitable for volatiles because of the mandatory evaporation step. Other frequently used methods include gas chromatography with a flame ionization detector (FID) or mass spectrometric detector (MSD) which has the capacity to reveal the type of hydrocarbons present and is applicable to both volatile and semivolatile samples. Ultraviolet fluorescence is another method that is available both as a portable field device and as off-site laboratory equipment. Each of the methods has its own advantages and disadvantages; hence, the choice of method is guided by the type of data needed as discussed in detail in this review. The distribution of TPHC in water and sediments across the globe and the factors influencing the distribution were also reviewed.
\end{abstract}

\section{Introduction}

Petroleum hydrocarbons (PHCs) are prominent among organic contaminants which are frequently disposed into the marine environment in lower concentrations in the form of urban runoffs, automobile wastes, stormwater, industrial effluents, or domestic wastes [1-3] and occasionally in higher concentrations as a major oil spill $[4,5]$. The main constituents of these PHCs are degraded crude oils, combusted fossil fuels, and normal alkanes [6,7]. They are generally less soluble in water but are readily adsorbed onto particulate matter and are subsequently scavenged to the bottom sediment which has become a reservoir for several hydrophobic contaminants. The danger in the sedimentation of these organic pollutants is their tendency to accumulate and bioconcentrate over time in aquatic organisms [8-10].
Total petroleum hydrocarbons (TPHCs) is the term generally used to describe the amount of petroleum-based hydrocarbon extracted and quantified by a particular method in an environmental matrix [11, 12]. TPHC analytical methods vary in scope to a great extent, with each providing results within a particular range, while some are nonspecific. Hence, understanding how the analysis was carried out is very crucial for correct interpretation of the results obtained. Methods with different extraction efficiencies could produce different TPHC concentrations for the same sample [13, 14]. Hence, results generated using different procedures are always difficult to compare because different calibration standards and extracting solvents are involved [6].

Petroleum hydrocarbons consist majorly of three groups of compounds, namely, alkanes, alkenes, and aromatics [15]. Alkanes are the key components of many refined petroleum 
products (e.g., gasoline, diesel fuel, kerosene, jet fuel, and heating oil) and are subdivided into several classes which include the following: linear alkanes (n-alkanes), branched alkanes, isoprenoids, cycloalkanes (e.g., steranes and triterpanes), and unresolved complex mixtures (UCM) which are difficult to resolve by capillary column gas chromatography $[6,16]$. The presence of UCM in chromatograms is usually an indication of petroleum degradation. They are commonly found in the high-molecular-weight range of the n-alkanes but are sometimes present in the low molecular range as well $[17,18]$.

TPHC is sometimes determined as the sum of concentrations of n-alkanes and UCM [19] or as the total concentration of all hydrocarbons eluting from n-nonane (C9) to n-hexatriacontane (C36) excluding the priority polycyclic aromatic hydrocarbons [20]. They are mostly found in the higher-molecular-weight range of the hydrocarbons and sometimes also in the low-molecular-weight range [21]. TPHC could also be measured as the sum of aliphatic and aromatic hydrocarbons, especially those in the following groups: C9 to C18 (aliphatic), C19 to C36 (aliphatic), and C11 to C22 (aromatic) [22-24].

Total petroleum hydrocarbons (TPHCs) themselves may not be a direct pointer of hazard to humans or the environment $[13,25]$, but their presence indicates the health status of the water body and is also used for source tracking of the contaminants in the coastal waters and sediments $[26,27]$. In this paper, we review the existing methods of extraction for petroleum hydrocarbon in water and solid samples, compare methods of final determination, and assess the levels of petroleum hydrocarbons in the aquatic environments across the globe and the available tools for source tracking using nalkanes as reference compounds.

\section{Physicochemical Properties}

2.1. Boiling Points. Generally, the boiling point of hydrocarbons (HCs) increases as the number of carbon atoms increases. For n-alkanes, an increase of approximately $20^{\circ} \mathrm{C}$ is observed for every addition of new carbon atom to the chain. PAHCs are characterized by higher melting points and boiling points than their corresponding n-alkanes and therefore they are solid in nature [28].

2.2. Solubility, Volatility, and Persistence. The extent of interaction of hydrocarbon structures with water depends on their degree of polarity. Aliphatic hydrocarbons are generally less polar and are therefore less soluble in water compared to their corresponding aromatic counterparts. For instance, the solubility of aliphatic hydrocarbons in the range of C5-C6 is $36 \mathrm{mg} / \mathrm{L}$ while aromatic hydrocarbons in the same range have solubility as high as $220 \mathrm{mg} / \mathrm{L}$. The most soluble components of the aromatic hydrocarbons are the lower-molecular-weight compounds. Therefore, solubility decreases as the number of the aromatic rings and molecular-weight increase. On the other hand, the aliphatic HCs are relatively more volatile than the aromatic HCs with a similar number of carbon atoms [29]. Nearly all the normal alkanes with carbon number less than 15 are lost by volatilization in the early days of spillage while those with carbon number greater than 20 are lost some weeks later $[13,30]$. Lower weight hydrocarbons are less persistent in the environment unlike the high-molecularweight hydrocarbons. Therefore, persistence of petroleum hydrocarbons rises as the boiling point of the compound increases [28].

2.3. Toxicity and Microbial Degradation. Aromatic hydrocarbons are considered to be relatively more toxic and more resistant to microbial degradation than the corresponding normal alkanes, isoalkanes, cycloalkanes, and the unsaturated aliphatic hydrocarbons [5, 31]. The degree of toxicity of contaminants in water will to a large extent depend on their level of solubility [28]. Microbial degradation of hydrocarbons is a function of many factors which include the level of dissolved oxygen, $\mathrm{pH}$, and microbial population in the environment. The population of the degrading bacteria can be lower in an unpolluted environment but can drastically increase when in contact with spilled petroleum substances [32-36].

The rate of susceptibility of hydrocarbons to microbial degradation differs from one class to another $[37,38]$ and bacteria can degrade aliphatic, alicyclic, and aromatic hydrocarbons of low to moderate weights at a higher rate when the environmental conditions are very ideal. However, the rate of biodegradation decreases as the resistance due to the increase in the molecular weight of the compounds increases [39]. The typical decreasing order of biodegradation is given as follows: n-alkanes $>$ branched alkanes $>$ low-molecular-weight aromatics $>$ cyclic alkanes $>$ high-molecular-weight aromatics. Aromatic hydrocarbons are generally less biodegradable than the corresponding aliphatic hydrocarbons $[5,37,38]$.

Oxygenases can convert alkanes to alcohol by the process of degradation. The alcohol can be oxidized to aldehyde and then to fatty acids which can subsequently be utilized in the $\beta$-oxidation of the aliphatic chain. In a similar manner, cycloalkanes can be degraded to cyclic alcohol by oxidases and then dehydrogenated to ketone. Similarly, aromatic hydrocarbons can be transformed to an epoxide through the action of oxygenases. The product can then be hydrated to trans-dihydrodiols which are later oxidized to catechols. Catechol can later be oxidized further to muconic acid or 2-hydroxymuconic semialdehyde [40] which can finally be degraded to yield organic acids that are used by microorganisms for cell synthesis and energy production [41].

\section{Sources of Petroleum Hydrocarbons in the Marine Environment}

Petroleum hydrocarbons in the marine environment come from natural (biogenic or diagenetic) and anthropogenic (petrogenic or pyrogenic) sources [42]. Biogenic source hydrocarbons refer to those hydrocarbons produced by living organisms (e.g., planktons, algae, and bacteria) or through biological processes involving terrestrial plants. Examples include C23-C33 aliphatic hydrocarbons which are largely produced by the terrestrial plant detritus and odd-numbered n-alkanes (C15, C17, and C19) from biogenic marine input 
which are usually available in low quantity [43]. Hydrocarbons from diagenetic sources are those produced as a result of physical and geochemical changes gone through by a sediment after its initial deposition as it changes into rock. They enter marine water mostly by natural seepage [44].

The anthropogenic hydrocarbons are usually more in the environment than the natural ones. They are commonly generated from various human activities like industrialization, urbanization, transportation, oil utilization, operations and storage, shipping, and fishing $[45,46]$. Abundance of C16, C18, and C20 in most cases suggests oil spillage [18] from tanks and oil pipelines constructed to transfer crude oil from one place to another [44]. For anthropogenic derived hydrocarbons, the level of odd-numbered alkanes is almost equal to that of the even-numbered ones, usually in the ratio $1: 1$ [43]. In the early 1980s, it was concluded that approximately $10 \%$ of the crude oil in the marine environment comes from natural oil seeps, and another $27 \%$ comes from oil production, refining, and transportation, while the balance of $63 \%$ originates from urban and river runoff, atmospheric emission, and municipal and industrial discharges, among others [44].

\section{Sample Collection and Preservation}

Sample collection and preparation strategies are very crucial in the analysis of petroleum hydrocarbons in the environment [47]. The sample must be collected without contamination and must be wholly representative of the environmental medium where it was taken $[11,13]$. The analyst must ensure that no bias or error is introduced into the samples during and after the collection. The sampling equipment must be thoroughly cleaned in between sampling points to avoid cross-contamination and the sample must be homogeneous. A minimum of one duplicate field sample is required in good practice for aqueous samples and space should be left for air above the sample to prevent overflow $[47,48]$.

The use of 1-liter amber glass bottles with Teflon-lined screw cap for aqueous sample collection is recommended. Samples are to be preserved at the time of collection with concentrated $\mathrm{HCl}$ or $\mathrm{H}_{2} \mathrm{SO}_{4}$ to $\mathrm{pH}<2$ and held at $4^{\circ} \mathrm{C}$ immediately after collection until extracted within 14 days of collection. However, unpreserved samples must be extracted within 7 days [23, 48, 49]. Soil or sediment samples are to be collected with a grab or core sampler or any other equipment as found appropriate in $120 \mathrm{~mL}$ wide-mouth glass jar or vessel of any other sizes, depending on the quantity of samples needed for the analysis [47]. The samples must be cooled to $4^{\circ} \mathrm{C}$ and extracted within 14 days of collection. Both the aqueous and the soil/sediment extracts must be analyzed within 40 days of extraction [11, 49]. A volume of $400 \mathrm{~mL}$ is the smallest aqueous sample size allowed for this analysis provided that the solvent/sample ratio is upheld [23].

Soil or sediment samples can be otherwise preserved at 4 $\pm 2^{\circ} \mathrm{C}$ at the time of collection and frozen thereafter at $-10^{\circ} \mathrm{C}$ within 48 hours. The sample must be extracted not later than 14 days when thawed and analyzed within the next 40 days. The frozen samples can be held for up to a year before analysis if need be but must be extracted within 24 hours of defrosting [48].

\section{Extraction and Cleanup Methods for TPHC in Water and Sediments}

The most commonly used extraction methods for the isolation of the semivolatile compounds from water, soil, and sediment samples prior to analytical determination are discussed below.

5.1. Water Samples. The most commonly used extraction method for TPHC in aqueous samples is the EPA 3510 liquid-liquid extraction $[5,50,51]$. Other available methods include continuous liquid-liquid extraction [11], solid phase extraction [51], vortex extraction [52], and microextraction [53].

The liquid-liquid extraction (LLE) technique involves the use of a separatory funnel for multiple extraction of the sample with an organic solvent of choice with the intent of achieving good recovery of the desired analytes. The technique requires strong shaking of the liquid sample with an organic solvent in a funnel shaped piece of glassware for a couple of minutes, followed by the separation of the organic layer (extract) from the aqueous phase. The extract is then filtered through a desiccant to remove moisture before a final concentration prior to the analytical procedure. The method is however labor-intensive and solvent consuming $[11,54]$. Another method is the EPA 3520 , the continuous liquid-liquid extraction (CLLE) which involves continuous recycling of fresh organic solvent in the form of droplets which are passed through the water sample. It is very efficient, requires less attention of the operator, and consumes very little volume of solvent. CLLE is very good for samples containing emulsionforming solids but has few disadvantages. It consumes more time (18-24 hours) than the conventional LLE (EPA 3510) and has a tendency to degrade the thermally unstable compounds, as well as lose some volatile ones in the process [11] (http://www.chemistry.sc.chula.ac.th/course_info/ 2302548/Wk3.pdf).

Solid phase extraction (SPE, EPA Method 3535) involves passing of a water sample through a cartridge containing an adsorbent like silica or alumina in which analytes are retained and afterwards eluted with a small portion of organic solvent $[11,55]$. It has better extraction efficiency and uses lesser solvent and glassware compared to LLE and CLLE. Sample transfer in SPE is very minimal, guaranteeing little or no cross-contamination [56]. Many laboratories are still using LLE and SPE today, even though they are time-consuming, because they are relatively inexpensive, simple, and highly efficient [57].

5.2. Solvent Selection. The choice of solvent used for organic extraction in relation to the type of material extracted determines to a very large extent the efficiency of such an extraction process. A good extracting solvent should have low boiling point, low miscibility with water, and high solubility for the desired analytes [58]. Other criteria to be considered in the choice of solvents include cost, toxicity, spectral qualities, availability, method regulations, and extraction efficiency [11]. Organic contaminants were in time past extracted with halogenated solvents like Freon 113 (trichlorotrifluoroethane) which were less toxic to humans and possess good infrared 
spectral qualities. However, they are presently being phased out globally because of their implication in ozone layer depletion. Possible replacements for these solvents include dichloromethane, pentane, n-hexane, tetrachloroethene, and carbon tetrachloride $[11,13,59]$.

Extraction efficiency of the organic analytes in aqueous samples is frequently monitored by the addition of surrogate standard solution (e.g., 1-chlorooctadecane for the n-alkanes; 2-fluorobiphenyl for the PAHs) to the sample matrix before extraction. Many laboratories are also performing matrix spikes with the intent of determining whether the compounds of interest are retained in the water, soil, or sediment matrices [60].

5.3. Solid Samples. The most frequently used methods for the extraction of soil and sediment samples prior to their analytical determination include conventional Soxhlet extraction $[27,61]$, ultrasonication $[52,62]$, vortex/mechanical shaking [63], accelerated solvent extraction [5, 64], and supercritical fluid extraction. Extraction efficiency for all these methods solely depends on the sample and solvent matrix [11].

Mechanical shaking is quite easy and suitable for petroleum hydrocarbon extraction from various environmental samples $[65,66]$. It involves shaking the sample with a solvent. Desiccant (e.g., $\mathrm{Na}_{2} \mathrm{SO}_{4}$ ) is sometimes added to remove humidity and facilitate the breaking of the sample, thereby increasing its surface area for excellent contact with the extracting solvent. However, it is not an approved standard method by the USEPA because its efficiency depends on the type of sample [11]. Soxhlet extraction (EPA Method SW8463540 ) is the most commonly used and it is quite efficient for the extraction of the semivolatiles. It involves heating and refluxing of the sample with a solvent continuously for a long period of time (16-48 hours or more) but generates a large volume of extract for concentration and it is less appropriate for the volatiles $[67,68]$.

Ultrasonic extraction (EPA Method SW-846 3550) method is also very appropriate for the semivolatiles. It uses sound waves (ultrasonic vibrations) to enhance the transfer of the desired compounds from the sample to the solvent. It is a faster method than Soxhlet extraction and requires a relatively lesser amount of solvent [11]. However, it is laborintensive in that it requires multiple extractions, decanting, and filtration for every sample processed. Accelerated solvent extraction (ASE) is another method for the extraction of semivolatile organic compounds. It is otherwise referred to as subcritical fluid extraction and has reportedly met the requirements for EPA Method 3545 (pressurized fluid extraction) in that it has wider coverage in its application and a good extraction efficiency equivalent to Soxhlet extraction method [67].

ASE uses organic solvents like dichloromethane for its operation. The solvent is heated and pressurized, before being passed through the sample for quick and efficient removal of the desired compounds from the sample matrix [11, 67]. The method requires a shorter extraction period and smaller volume of solvent compared to the conventional methods and, thus, it is a good alternative to both Soxhlet and ultrasonic extraction $[23,68]$. However, it is an expensive technique and has the tendency of extracting many interferences together with the desired analytes because of the high temperature it uses for its operation. Therefore, column cleanup may be required after the extraction process before the analytical determination. Moreover, the extraction process is though shorter compared to Soxhlet extraction method but the preparation time for the extraction cells is long and rinsing consumes a lot of solvent $[68,69]$.

Supercritical fluid extraction (SFE) is a standard EPA method for total recoverable petroleum hydrocarbons (3540) and polycyclic aromatic hydrocarbons (3561). It involves heating and pressuring of the mobile phase (e.g., $\mathrm{CO}_{2}$ ) to supercritical levels, whereby it possesses the properties of both gas and liquid (supercritical fluid). The fluid is then passed through the sample for the concentration of the analytes on a particular sorbent, after which they are eluted with a solvent and analyzed conventionally [11].

5.4. Column Cleanup and Separation. Column cleanup is a process used to separate organic analytes from their interfering compounds of different polarity which were possibly coextracted along with the analytes [70]. It is a very important aspect of infrared-based and gravimetric methods because they are very sensitive to nonpetroleum interferences. It is however not commonly utilized in gas chromatographybased methods because the presence of interfering compounds is not difficult to identify by experienced analysts [11].

Such interferences include the following:

(i) Natural organics that are not related to petroleum, for example, animal and vegetable derived hydrocarbons.

(ii) Oxygenated metabolites from biodegraded petroleum origin, for example, organic acids, alcohols, ketones, aldehydes, and phenols.

(iii) Artifacts from laboratory or sampling equipment, for example, phthalates.

(iv) Non-petroleum-related chemicals, for example, pesticides and chlorinated solvents [70].

In the infrared-based and gravimetric category, a small quantity of silica gel is added to the extract vial and shaken to remove the polar compounds before the analysis whereas, in the GC methods, the adsorbent (e.g., silica gel) is packed into a glass column. The sample extract is then run through the column which retains the polar substances while the compounds of interest are eluted with an appropriate solvent. This is followed by reconcentration of the eluates and analysis [70]. Aside from the cleaning of the extract, silica gel column also fractionates the petroleum hydrocarbon extract into aliphatic and aromatic fractions for separate determination $[13,48]$.

\section{Analytical Procedures for TPHC in Water and Sediments}

There are many conventional analytical methods available for the measurement of TPHC concentrations in various environmental samples. Some are more applicable for field 
screening while others are suitable for laboratory uses [11, 13, 71]. The most commonly used include infrared (IR) spectroscopy (EPA Method 418.1), gravimetry (EPA Method $1664 \mathrm{~A}$ ), gas chromatography with flame ionization detection (GC/FID) (EPA Method 8015), gas chromatography with mass spectrometric detection (GC/MSD) (EPA Methods 8270 and 625), ultraviolet spectrophotometry, immunoassay (IMA) (EPA Methods 4030 and 4035), Raman spectroscopy, and fluorescence spectroscopy $[8,52,72,73]$. Liquid samples are mostly prepared for analytical determination by liquidliquid extraction (LLE) or solid phase extraction (SPE) while solid samples are commonly made ready by Soxhlet extraction method [74]. This section will therefore present the strengths and weaknesses of some of the methods.

6.1. Gravimetric Method. There are basically two gravimetric EPA methods. These include EPA 413.1 for oil and grease and EPA 1664A for silica gel n-hexane extractable material (also regarded as total petroleum hydrocarbons). They both involve solvent extraction, evaporation, and weighing to a constant weight [52] but the oil and grease method does not differentiate the polar organic matter from the petroleum hydrocarbon portion [74]. EPA 1664A was developed to replace EPA 413.1 that uses Freon 113 (a Class I ozonedepleting substance) as its extracting solvent. The new method performs extraction with n-hexane which is more environmentally friendly but flammable and could determine total petroleum hydrocarbon concentration in the same procedure for the oil and grease analysis [75].

EPA 1664A procedure begins with adjustment of the aqueous sample $\mathrm{pH}$ to a value less than 2 with either $\mathrm{H}_{2} \mathrm{SO}_{4}$ or $\mathrm{HCl}$. The sample is then extracted with $\mathrm{n}$-hexane using LLE (or SPE) method and the organic portion is filtered through a funnel containing anhydrous $\mathrm{Na}_{2} \mathrm{SO}_{4}$, after which the solvent is distilled off from the flask at $85^{\circ} \mathrm{C}$ in a water bath. The flask is then dried and weighed to constant weight for the estimation of the oil and grease concentration [75]. For the TPHC determination, the oil and grease in the flask is dissolved in fresh portion of $\mathrm{n}$-hexane. A suitable amount of silica gel is added to remove the polar substances (e.g., fats, dyes, oils, waxes, and some heavier organic molecules from animals and plants origin) in the extract and the mixture is stirred using a magnetic stirrer, filtered, and gravimetrically determined as nonpolar material (NPM), also known as silica gel treated $\mathrm{n}$-hexane extractable material (SGT-HEM) [74, 76].

Solid samples (sludge, soil, and sediment) are catered for in the EPA SW-846 Test Method 9071B in which a wet sample is to be acidified with concentrated $\mathrm{HCl}$. Acidified sludge sample is dried with either anhydrous sodium sulphate or magnesium sulphate and soil or sediment sample with sodium sulphate prior to the Soxhlet extraction with nhexane. The NPM and SGT-HEM in the sample are thereafter gravimetrically determined as earlier described in the EPA 1664 procedures [77]. Other gravimetric methods reported for solid samples involved the addition of $3 \mathrm{~g} \mathrm{KOH}$ (to enhance the extraction of the humic substances) and $100 \mathrm{~cm}^{3}$ methanol to about $100 \mathrm{~g}$ air-dried samples prior to the Soxhlet extraction process. The subsequent steps involving gravimetric measurement of the polar and nonpolar compounds are as discussed above [78-80].

Gravimetric determination of TPHC in environmental samples is quite simple and affordable and has thereby gained a very huge patronage over the years because it does not require any special equipment. However, it is more applicable to samples with high concentration of analytes because of its low sensitivity. It is time-consuming, especially at the solvent evaporation stage, and has great tendency of losing the lowmolecular-weight compounds, thereby introducing errors into the measurement $[58,73]$. The extraction efficiency of the solvent is relatively low for the higher-molecularweight compounds but can be reasonably enhanced with the addition of salt (sodium chloride). The coextraction of some organic matter with many polar functional groups is also encouraged by the low polarity of the solvent $[81,82]$.

6.2. Infrared Spectrophotometry. Similarly, two infrared (IR) based methods are in use for petroleum hydrocarbon related measurements. They include EPA 413.2 for total recoverable oil and grease (TOG) and EPA 418.1 for total recoverable petroleum hydrocarbons (TRPHCs) [13]. The oil and grease method is limited in application unlike EPA 418.1 or the modified EPA 801.5 which was widely accepted as a standard method for the assessment of hydrocarbon levels in the petroleum contaminated sites $[13,46]$. The method is capable of determining different classes of hydrocarbon as either oil and grease $(\mathrm{OG})$, gasoline range organics (GRO), or total petroleum hydrocarbons (TPHCs) [46]. It uses light absorption of the $\mathrm{CH}_{2}$ bond at $2930 \mathrm{~cm}^{-1}$ which is characteristic of the oil and grease for its measurement [58].

EPA 418.1 involves acidification of the water sample to $\mathrm{pH}<2$, extraction of the analytes from the sample matrix using 1,1,2-trichloro-1,2,2-trifluoroethane (Freon 113) or tetrachloromethane $\left(\mathrm{CCl}_{4}\right)$, and filtration of the extract through anhydrous sodium sulphate for moisture removal. The filtered extract is then made up to $100 \mathrm{~mL}$ with the extraction solvent and then stirred with a sufficient quantity of silica gel for the removal of the fatty matter before the absorbance measurement from $3200 \mathrm{~cm}^{-1}$ to $2700 \mathrm{~cm}^{-1}$. The final reading is then compared with the absorbance of a reference oil standard $[13,75]$. The advantages of the method include elimination of the solvent evaporation step, making it more appropriate for the volatile components of petroleum $[58,79]$. The measurement is very reproducible and more accurate, saves time, and is relatively easier [82]. Generally, IR methods give higher results than gravimetric methods, possibly because of the loss of volatile components due to the evaporation step in the latter [58].

However, IR readings sometimes may not suggest petroleum contamination in water or sediment sample because some compounds from nonpetroleum origin (e.g., humic or fulvic acid) may generate strong absorbance in the infrared range, yielding a false positive result especially when the cleanup step is omitted [52,59]. It is also limited in its application as no adequate information is provided on the type of hydrocarbon present. The halogenated solvents (Freon, $\mathrm{CCl}_{4}$ ) used for extraction in this method 
are though relatively nontoxic and nonflammable but are primary sources of ozone-layer-depleting substances which were required to be phased out in the Clean Air Act Amendments of 1990 [46]. EPA 418.1 is therefore being gradually replaced with EPA gravimetric (EPA 1664) and/or gas chromatographic (e.g., ISO $9377-2$ or $8015 \mathrm{D})$ method $[52,76,82]$.

6.3. Gas Chromatography. The revised EPA 8015D called "Non-Halogenated Organics Using GC/FID" was specifically developed to take care of volatile and semivolatile organics separately as gasoline range organics (GRO) in the boiling point range of $60^{\circ} \mathrm{C}-170^{\circ} \mathrm{C}(\mathrm{C} 6-\mathrm{C} 10)$ and diesel range organics (DRO) in range of $170^{\circ} \mathrm{C}-430^{\circ} \mathrm{C}(\mathrm{C} 10$ to $\mathrm{C} 28)$. The method has the ability to provide some necessary information on the product type unlike the gravimetric and IR methods [13]. The volatile samples are usually introduced into the gas chromatograph (GC) by purge and trap method (EPA 5030 for aqueous or EPA 5035 for solid sample) $[52,83]$.

Aqueous semivolatile samples are mostly prepared by liquid-liquid extraction (EPA 3510) technique, although solid phase extraction (EPA 3535) may as well be used. Solid samples are usually extracted with Soxhlet device (EPA 3540). The extracts are subjected to either alumina (EPA 3611) or silica gel (EPA 3630) column cleanup with which the fatty matter is removed on the basis of polarity and petroleum hydrocarbons are fractionated into aliphatic and aromatic fractions. Each fraction is then injected directly into a gas chromatograph equipped with a nonpolar capillary column for analytical determination [11, 83]. Identification of analytes is done by comparing the retention time of an individual compound to that of a reference standard. Calibration standards are used to prepare calibration curves with which the compounds of interest are quantified [11].

The aliphatic and aromatic fractions are analyzed separately on the gas chromatograph using a flame ionization detector (GC-FID) which is mostly preferred for its relative sensitivity and selectivity for hydrocarbons. The two fractions are usually divided into carbon number ranges (GRO and DRO) on the basis of the PAH and n-alkane markers, respectively $[52,84]$. The areas covered by the resolved and unresolved (UCM) components are most commonly estimated to determine the total petroleum hydrocarbon (TPHC) level in the sample [84-86]. Unfractionated extract can also be quantified as the oil and grease, yielding a concentration greater than the sum of the aliphatic and aromatic fractions [84].

Total hydrocarbons are sometimes measured with FID while the aromatic fraction is determined with a photoionization detector (PID). The aliphatic fraction is therefore estimated by subtracting the aromatic from the total hydrocarbon result. However, PID is not entirely selective for aromatic compounds and therefore can overestimate [13]. Alternatively, GC coupled with mass spectrometric detector (MSD), especially in the selected ion monitoring (SIM) mode, can produce a better result in the analysis of aromatic compounds. This is because it has the capacity to detect a compound present at an extremely low concentration in a complex matrix, provided that the desired compound has a prominent fragment ion at a mass that differentiates it from other hydrocarbon compounds and can also offer more comprehensive information about the identity of the compound $[52,72]$.

With GC methods, the identity of the fresh to mildly degraded oil can be unraveled in the environmental samples for pattern recognition [86]. The profile of unresolved complex mixtures (UCM) in the contaminated samples can be adequately characterized and resolved [87]. But the cost of analysis, operational time required, and sample matrix effects may be higher [88]. Overlap of carbon number ranges could be another challenge because a section of the GRO may be reported as DRO and vice versa $[13,52]$.

6.4. Ultraviolet Fluorescence Spectrophotometry. Ultraviolet fluorescence (UVF) spectrophotometry is a fast and valuable screening method for TPHC analysis in the environmental samples. It involves solvent extraction and optical measurement of the hydrocarbon molecules using an ultraviolet fluorescence spectrometer. It is always used in the field for aqueous samples without solvent extraction [58, 74, 89]. The aromatic hydrocarbons fluoresce when their $\pi$ bonds are excited by ultraviolet light and the hydrocarbon concentration in the sample extracts is measured using a fluorometer [74]. The technique has greater potential to distinguish low-molecular-weight aromatic hydrocarbons with 2 to 3 rings from the high-molecular-weight compounds $[11,58]$. North Carolina in the United States has recently approved the method for monitoring spillage from leaking underground storage tanks as a replacement for the GC/FID (EPA 8015D) method [90]. However, aliphatic alkanes do not respond to ultraviolet radiation because they do not have $\pi$ bonds. Therefore, samples containing paraffinic oil cannot be detected by this method [74].

For reliable analytical results, a calibration curve must be prepared using specific hydrocarbon contaminants. Analytical recovery of UVF was reportedly good with n-hexane $(132 \%)$ as an extraction solvent compared with methanol (40\%) [74] but the accuracy and reproducibility at a low concentration range were found to be relatively low [82]. It is not a suitable method for fingerprint analysis because nonhydrocarbon compounds can also emit at the same wavelength as the analytes, thus causing interference [89].

\section{Levels of Total Petroleum Hydrocarbons in the Environment}

The total petroleum hydrocarbon results published from different countries across the world are presented in Tables 1 and 2. The levels reported in water matrix ranged from "not detected" (ND) to $260,000 \mu \mathrm{g} / \mathrm{L}$. The highest values $(60,000-260,000 \mu \mathrm{g} / \mathrm{L})$ were recorded in the Deepwater Horizon, Gulf of Mexico [91], while the lowest values $(0.05-4.13 \mu \mathrm{g} / \mathrm{L})$ were found in the Gulf of Thailand and East Coast of Peninsular Malaysia [6]. The first world immense accidental blowout occurred in June 1979 at the Ixtoc-I most productive oil well in the Gulf of Mexico where more than 3.4 million barrels were spilled [92]. This might be responsible for the higher level of TPHC measured from the 
TABLE 1: Levels of TPHC in water samples around the world $(\mu \mathrm{g} / \mathrm{L})$.

\begin{tabular}{|c|c|c|c|}
\hline Sample source & Concentrations reported & Analytical method & References \\
\hline \multicolumn{4}{|c|}{ Africa } \\
\hline $\begin{array}{l}\text { Groundwater samples collected in some communities in Rivers } \\
\text { State, Nigeria }\end{array}$ & $33,076(\max )$ & GC/FID & {$[63]$} \\
\hline Ubeji surface water, Warri, Nigeria & 73,500 & Gravimetry & [96] \\
\hline $\begin{array}{l}\text { Surface water from the vicinity of Nigerian National Petroleum } \\
\text { Corporations (NNPC) Oil Depot in Apata, Ibadan Metropolis, } \\
\text { Nigeria }\end{array}$ & $20,340-27,400$ & Gravimetry & [110] \\
\hline $\begin{array}{l}\text { Groundwater in communities in Niger } \\
\text { Delta region of Nigeria }\end{array}$ & $1,352-12,110$ & GC-FID & [111] \\
\hline \multicolumn{4}{|l|}{ 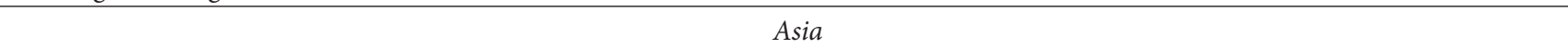 } \\
\hline Strait of Johor, in Peninsular Malaysia & $25-2,795$ & - & [112] \\
\hline Bohai Bay, China & $24-508$ & - & [109] \\
\hline Main Outfall Drain in Al-Nassiriya City, Southern Iraq & $0.01-8.76$ & UVF & [113] \\
\hline Setiu Wetlands, Terengganu, Malaysia & $4-121$ & UVF & {$[114]$} \\
\hline Coastal waters from Malaysian west coast & $5-386$ & - & [112] \\
\hline Dungun River basin water, Malaysia & $12-41$ & UVF & [50] \\
\hline Gulf of Thailand and East Coast of Peninsular Malaysia & $0.05-4.13$ & UVF & {$[6]$} \\
\hline Levantine Basin, Israeli Coastline & $19-88$ & - & [115] \\
\hline Northwestern Arabian Gulf & $1.2-546$ & - & [116] \\
\hline \multicolumn{4}{|c|}{ America } \\
\hline Jamaica Bay, New York Metropolitan Area & $10-20$ & GC/FID, UVF \& GC/MS & [117] \\
\hline Deepwater Horizon, Gulf of Mexico & $60,000-260,000$ & - & [91] \\
\hline Ixtoc-I Blowout, Gulf of Mexico & $5-106,000$ & - & [93] \\
\hline \multicolumn{4}{|c|}{ Europe } \\
\hline Seawater of North Cape (Norway) & 483 (mean) & GC/MS & {$[72]$} \\
\hline Romanian Black Sea Sector & $29-271$ & UVF & [118] \\
\hline Kara Sea & $8-408$ & - & [119] \\
\hline Pechora Sea & $2-87$ & - & {$[120]$} \\
\hline \multicolumn{4}{|c|}{ Australia } \\
\hline Yellow Water, Kakadu National Park & ND-200 & GC/FID & [121] \\
\hline
\end{tabular}

site some years later [93]. Another spill in the region from an oil well in the Deepwater Horizon popularly referred to as "the worst environmental disaster in the history of the US" claimed not less than 11 lives in April 2010. About 4.2 million barrels were reportedly spilled in the ugly incidence that lasted for about 87 days in which British Petroleum (BP) was implicated, hence the reason for higher TPHC level in the study conducted at the site about three years later [91, 94].

The European Union's target value for TPHC in estuary and harbor water is $300 \mu \mathrm{g} / \mathrm{L}$. This value was greatly exceeded in many water bodies across the world, signifying anthropogenic input of hydrocarbons into the environments [95]. With reference to the collated data as shown in Table 1, TPHC levels were exceptionally higher in the Gulf of Mexico and the Niger Delta region of Nigeria, where petroleum exploration activities are being undertaken, than in other regions $[63,91$, 93, 96].

Table 2 showed that the TPHC levels in the sediment samples analyzed across the world varied from ND (not detected) to $16,500 \mathrm{mg} / \mathrm{kg}$. The lowest values (ND-1.71 mg/kg) were recorded from the coastline and mangroves of the Northern Persian Gulf [97] and the highest ones (300-16,500 mg/kg) were recorded from the Pearl River Estuary, China [98]. The minimum value of $10 \mathrm{mg} / \mathrm{kg}$ stipulated by the United Nations Environment Programme was exceeded in most countries, suggesting increasing petroleum hydrocarbon pollution in the fresh and marine aquatic environments across the globe. Urban-industrial activities can increase the concentration to between 10 and $1,000 \mathrm{mg} / \mathrm{kg}$ while levels $>3,000 \mathrm{mg} / \mathrm{kg}$ will usually be found in oil spill sites $[4,99,100]$. This indicates a greater influence of industrial activities as well as oil spillage on the petroleum hydrocarbon levels in most of the coastal sediments all over the world. The levels were extremely higher in some estuaries in China [56, 98, 101-103], Ceuta Harbor in North Africa [104], São Gonçalo Channel in Pelotas, Rio Grande do Sul, Brazil [22], and Clyde Estuary, United Kingdom [105]. TPHC was generally much higher in the sediment than in the water column. 
TABLE 2: Levels of TPHC in sediment samples around the world (mg/kg).

\begin{tabular}{|c|c|c|c|}
\hline Sample source & Concentrations reported & Analytical method & References \\
\hline \multicolumn{4}{|c|}{ Africa } \\
\hline Ceuta Harbor, North Africa & $496-6,972$ & Gravimetry & {$[104]$} \\
\hline $\begin{array}{l}\text { Soil in communities in Niger } \\
\text { Delta region of Nigeria }\end{array}$ & $1,242-5,200$ & GC-FID & {$[111]$} \\
\hline Bizerte Lagoon, Tunisia & $0.05-20$ & - & {$[122,123]$} \\
\hline \multicolumn{4}{|c|}{ Asia } \\
\hline Arabian Gulf & 444 (mean) & UVF & {$[124]$} \\
\hline Bohai Bay, China & $6.3-535$ & UVF & {$[125]$} \\
\hline Arabian Gulf sediment, Kuwait & $50-1,122$ & UVF & {$[78]$} \\
\hline Musa Bay sediments & $17-97$ & UVF \& GC/MS & {$[126]$} \\
\hline Khowr-e Musa Bay & $18-89$ & UVF \& GC/MS & [127] \\
\hline Coastal Area of Putatan and Papar, Sabah & $0.26-4.59$ & UV/VIS & [128] \\
\hline Main Outfall Drain in Al-Nassiriya City, Southern Iraq & $0.09-5.70$ & UVF & [113] \\
\hline Coastline and mangroves of the Northern Persian Gulf & ND-1.71 & UVF & [97] \\
\hline Southeast Coast of India & $2.2-5.6$ & UVF & {$[8]$} \\
\hline Koh Sichang-Sriracha, Thailand & $1.1-153.4$ & UVF & [99] \\
\hline Saudi Arabia & $62-1,400$ & & {$[129]$} \\
\hline Changjiang Estuary, China & $2,200-11,820$ & - & {$[56,101]$} \\
\hline Pearl River Estuary, China & $300-16,500$ & - & {$[98,102,103]$} \\
\hline \multicolumn{4}{|c|}{ America } \\
\hline São Gonçalo Channel, Pelotas, Rio Grande do Sul, Brazil & $177-5,893$ & Gravimetry/GC/MS & {$[22]$} \\
\hline Barnegat-Bay-Little Egg Harbor Estuary, USA & $47-1,003$ & Iatroscan Mk6s/FID & {$[130]$} \\
\hline Galveston Bay, USA & $4.2-1,814$ & - & {$[131,132]$} \\
\hline Todos os Santos Bay, Brazil & $1.6-11$ & GC/MS & {$[133]$} \\
\hline Trinidad Coast & $3.0-1,824$ & UVF & {$[134]$} \\
\hline \multicolumn{4}{|c|}{ Europe } \\
\hline Clyde Estuary, UK & $34-4,386$ & Iatroscan Mk6s/FID & {$[105]$} \\
\hline
\end{tabular}

General assessment of the analytical methods employed by researchers for the determination of total petroleum hydrocarbons in both water and sediment matrices as shown in Tables 1 and 2 revealed greater use of UVF which was quicker and easier than other existing methods [106]. Although the equipment is mostly available as a portable field device, any data obtained should often be validated with offsite laboratory equipment for better quality and reliability [107]. The IR method (EPA 418.1) is gradually fading away because of the mandated halogenated solvents which are environmentally unfriendly, as gas chromatographic and gravimetric (EPA 1664) procedures are now increasing in patronage [108]. Total petroleum hydrocarbon is more determined in the Asian environment than in other continents of the world probably because of the great abundance of crude oil in many countries in the region. It is very obvious that spillage of oil, industrial effluent discharge, and urban runoff are the major reasons for higher TPHC levels in marine environment and therefore steps should be taken to minimize these to the barest minimum across the globe [109].

\section{Conclusion}

Although solid phase extraction has a better extraction efficiency than LLE, its application in the petroleum hydrocarbon extraction from the water matrix is limited because it is yet to be validated by the United States Environmental Protection Agency for this particular analysis. Therefore, LLE remains the most commonly used method because of its affordability, simplicity, and relative efficiency. Similarly, the solid samples are more commonly extracted with Soxhlet extractor which is time-consuming compared to the accelerated solvent extraction because it is easy to use and quite cheaper. Aliphatic hydrocarbons which are the primary components of petroleum hydrocarbons are mostly more determined in the marine sediment than in the water column because they have relatively low solubility in water and thereby concentrate in the bottom sediment.

Many analytical methods are available for the TPHC measurement in the environmental samples. Some measure TPHC on the basis of the aliphatic or aromatic fraction alone while few others combine the two fractions for the 
measurement. The results taken using different methods are therefore in most cases incomparable owing to their different background. However, off-site laboratory equipment is more preferred for the analytical determination of the analytes than the portable field devices because it generates good data which are much more reliable. The TPHC concentrations were found to be extremely higher in the spillage sites and greatly industrialized areas. Hence, there is a greater need for compliance with environmental laws as regards the oil exploration and transportation, as well as waste discharge into the marine environment in order to ensure safety of aquatic and human lives.

\section{Conflicts of Interest}

The authors declare that there are no conflicts of interest regarding the publication of this paper.

\section{References}

[1] V. Hatje, T. E. Payne, D. M. Hill, G. McOrist, G. F. Birch, and R. Szymczak, "Kinetics of trace element uptake and release by particles in estuarine waters: effects of $\mathrm{pH}$, salinity, and particle loading," Environment International, vol. 29, no. 5, pp. 619-629, 2003.

[2] C. Olver, Report on Issues Relating to the Potential Relocation of the Port Elizabeth Manganese Terminal and Tank Farm to the Port of Ngqura, Port Elizabeth Regional Chamber of Commerce, Port Elizabeth, South Africa, 2008.

[3] River Health Programme (RHP), State-of-Rivers Report: Buffalo River System, Department of Water Affairs and Forestry, Pretoria, South Africa, 2004.

[4] G. M. M. Tehrani, R. Hshim, S. H. Halim, S. B. Tavakoly Sany, R. Khani jazani, and Z. Monazami Tehrani, "Assessment of contamination by petroleum hydrocarbons in sediments of Musa Bay, Northwest of the Persian Gulf-Iran," International Proceedings of Chemical, Biological and Environmental Engineering, vol. 33, pp. 75-80, 2012.

[5] O. E. Ahmed, S. A. Mahmoud, and A. E. M. Mousa, "Aliphatic and poly-aromatic hydrocarbons pollution at the drainage basin of Suez Oil Refinery Company," Current Science International, vol. 4, no. 1, pp. 27-44, 2015.

[6] P. Wongnapapan, G. Wattayakorn, and A. Snidvongs, "Petroleum hydrocarbon in seawater and some sediments of the South China Sea, Area I: Gulf of Thailand and East Coast of Peninsular Malaysia," in Proceedings of the 1st Technical Seminar on Marine Fishery Resources Survey in the South China Sea, pp. 105-110, 1999.

[7] G. Wattayakorn, "Petroleum pollution in the Gulf of Thailand: a historical review," Coastal Marine Science, vol. 35, no. 1, pp. 234-245, 2012.

[8] A. Muthukumar, G. Idayachandiran, S. Kumaresan, T. A. Kumar, and T. Balasubramanian, "Petroleum hydrocarbons (PHC) in sediments of three different ecosystems from Southeast Coast of India," International Journal of Pharmaceutical \& Biological Archives, vol. 4, no. 3, pp. 543-549, 2013.

[9] J. W. Farrington and H. Takada, "Persistent organic pollutants (POPs), polycyclic aromatic hydrocarbons (PAHs), and plastics: examples of the status, trend, and cycling of organic chemicals of environmental concern in the ocean," Oceanography, vol. 27, no. 1, pp. 196-213, 2014.
[10] S. A. M. Ali, C. Payus, and M. M. Ali, "Surface sediment analysis on petroleum hydrocarbon and total organic carbon from coastal area of papar to Tuaran, Sabah," Malaysian Journal of Analytical Sciences, vol. 19, no. 2, pp. 318-324, 2015.

[11] W. Weisman, Ed., Analysis of Petroleum Hydrocarbons in Environmental Media (Total Petroleum Hydrocarbon Criteria Working Group Series), vol. 1, Amherst Scientific Publishers, Amherst, Mass, USA, 1998.

[12] Institute for Environmental and Coastal Management (IECM), "Port of Ngqura: marine biomonitoring programme. Annual Report 2002-2003," Tech. Rep. C86, Institute for Environmental and Coastal Management, Port Elizabeth, South Africa, 2003.

[13] Agency for Toxic Substances and Disease Registry (ATSDR), Toxicological Profile for Total Petroleum Hydrocarbon, US Department of Health and Human Services, Public Health Service, Atlanta, Ga, USA, 1999.

[14] J. G. Speight, The Chemistry and Technology of Petroleum, vol. 137 of Chemical Industries, CRC Press, 2014.

[15] P. E. Wigger and B. E. Torkelson, "Petroleum hydrocarbon fingerprinting: numerical interpretation developments," in Proceedings of the International Petroleum Environmental Conference, San Antonio, Tex, USA, 1997.

[16] M. A. de Abreu-Mota, C. A. de Moura Barboza, M. C. Bícego, and C. C. Martins, "Sedimentary biomarkers along a contamination gradient in a human-impacted sub-estuary in Southern Brazil: a multi-parameter approach based on spatial and seasonal variability," Chemosphere, vol. 103, pp. 156-163, 2014.

[17] A. T. Revill, M. R. Carr, and S. J. Rowland, "Use of oxidative degradation followed by capillary gas chromatography-mass spectrometry and multi-dimensional scaling analysis to fingerprint unresolved complex mixtures of hydrocarbons," Journal of Chromatography A, vol. 589, no. 1-2, pp. 281-286, 1992.

[18] M. Sakari, B. S. Hsia, R. Tahir et al., "Estuary and sea-associated wetlands as final sink for organic pollutants: a case study in Sabah, Malaysia," International Journal of Environment and Bioenergy, vol. 9, no. 1, pp. 1-16, 2014.

[19] R. R. Harji, A. Yvenat, and N. B. Bhosle, "Sources of hydrocarbons in sediments of the Mandovi estuary and the Marmugoa harbour, west coast of India," Environment International, vol. 34, no. 7, pp. 959-965, 2008.

[20] R. Klee, Selection of Analytical Methods to Characterize Petroleum Releases Guidance Document, Connecticut Department of Energy \& Environmental Protection, 2015.

[21] M. A. Gouch, M. M. Rhead, and S. J. Rowland, "Biodegradation studies of unresolved complex mixtures of hydrocarbons: model UCM hydrocarbons and the aliphatic UCM," Organic Geochemistry, vol. 18, no. 1, pp. 17-22, 1992.

[22] P. J. Sanches Filho, E. M. Böhm, G. M. Böhm, G. O. Montenegro, L. A. Silveira, and G. R. Betemps, "Determination of hydrocarbons transported by urban runoff in sediments of São Gonçalo Channel (Pelotas-RS, Brazil)," Marine Pollution Bulletin, vol. 114, no. 2, pp. 1088-1095, 2017.

[23] Washington State Department of Ecology (WSDE), "Analytical methods for petroleum hydrocarbons," Publication no. ECY 97602, Department of Ecology Publications Distribution Center, Olympia, Wash, USA, 1997.

[24] J. M. Guerra-García, F. J. González-Vila, and J. C. GarcíaGómez, "Aliphatic hydrocarbon pollution and macrobenthic assemblages in Ceuta harbour: a multivariate approach," Marine Ecology Progress Series, vol. 263, pp. 127-138, 2003. 
[25] United States Department of Health and Human Services (USDHHS), Toxicological Profile for Total Petroleum Hydrocarbons (TPH), Public Health Service Agency for Toxic Substances and Disease Registry, 1999.

[26] H. Zaghden, M. Kallel, A. Louati, B. Elleuch, J. Oudot, and A. Saliot, "Hydrocarbons in surface sediments from the Sfax coastal zone, (Tunisia) Mediterranean Sea," Marine Pollution Bulletin, vol. 50, no. 11, pp. 1287-1294, 2005.

[27] I. Zrafi, L. Hizem, H. Chalghmi, A. Ghrabi, M. Rouabhia, and D. Saidane-Mosbahi, "Aliphatic and aromatic biomarkers for petroleum hydrocarbon investigation in marine sediment," Journal of Petroleum Science Research, vol. 2, no. 4, pp. 145-155, 2013.

[28] World Health Organization (WHO), "Petroleum products in drinking-water: background document for development of WHO guidelines for drinking-water quality," Tech. Rep. WHO/SDE/WSH/05.08/123, 2005.

[29] H. I. Abdel-Shafy and M. S. M. Mansour, "A review on polycyclic aromatic hydrocarbons: source, environmental impact, effect on human health and remediation," Egyptian Journal of Petroleum, vol. 25, pp. 107-123, 2016.

[30] K. Scally, The use of forensic polycyclic aromatic hydrocarbon signatures and compound ratio analysis techniques (CORAT) for the source characterisation of petrogenic/pyrogenic environmental releases [Master of Science Thesis], Higher Education and Training, Galway Mayo Institute of Technology, 2005.

[31] S. F. Mehanna and F. I. El-Gammal, "Gulf of Suez fisheries: current status, assessment and management," Journal of King Abdulaziz University (Marine Sciences), vol. 18, pp. 3-18, 2007.

[32] A. I. Okoh, "Biodegradation of Bonny light crude oil in soil microcosm by some bacterial strains isolated from crude oil flow stations saver pits in Nigeria," African Journal of Biotechnology, vol. 2, no. 5, pp. 1014-1108, 2003.

[33] A. I. Okoh, A. O. Olaniran, and P. Golyshin, "Dechlorination of 1,2- Dichloroethane by Pseudomonas aeruginosa OK1 isolated from a waste dumpsite in Nigeria," African Journal of Biotechnology, vol. 3, no. 10, pp. 508-511, 2004.

[34] A. I. Okoh, "Biodegradation alternative in the cleanup of petroleum hydrocarbon pollutants," Biotechnology and Molecular Biology Reviews, vol. 1, no. 2, pp. 38-50, 2006.

[35] A. I. Okoh and M. R. Trejo-Hernandez, "Remediation of petroleum hydrocarbon polluted systems: exploiting the bioremediation strategies," African Journal of Biotechnology, vol. 5, no. 25, pp. 2520-2525, 2006.

[36] S. D. Williams, D. E. Ladd, and J. J. Farmer, "Fate and transport of petroleum hydrocarbons in soil and groundwater at big south fork National River and recreation area, Tennessee and Kentucky, 2002-2003," U.S. Geological Survey Scientific Investigations Report 2005-5104, 2006.

[37] P. Fusey and J. Oudot, "Relative influence of physical removal and biodegradation in the depuration of petroleumcontaminated seashore sediments," Marine Pollution Bulletin, vol. 15, no. 4, pp. 136-141, 1984.

[38] J. G. Leahy and R. R. Colwell, "Microbial degradation of hydrocarbons in the environment," Microbiological Reviews, vol. 54, no. 3, pp. 305-315, 1990.

[39] T. H. Wiedemeier, J. T. Wilson, D. H. Kampbell, R. N. Miller, and J. E. Hansen, Technical Protocol for Implementing the Intrinsic Remediation with Long-term Monitoring Option for Natural Attenuation of Dissolved-phase Fuel Contamination in Groundwater, U.S. Air Force Center for Environmental Excellence, Brooks Air Force Base, San Antonio, Tex, USA, 1995.
[40] C. E. Cerniglia, "Microbial transformation of aromatic hydrocarbons," in Petroleum Microbiology, R. M. Atlas, Ed., pp. 99128, Macmillan Publishing Co, New York, NY, USA, 1984.

[41] V. Kothari, M. Panchal, and N. Srivastava, Microbial Degradation of Hydrocarbons, Institute of Science, Nirma University, Ahmedabad, India, 2013.

[42] Y. Wu, J. Zhang, T.-Z. Mi, and B. Li, "Occurrence of n-alkanes and polycyclic aromatic hydrocarbons in the core sediments of the Yellow Sea," Marine Chemistry, vol. 76, no. 1-2, pp. 1-15, 2001.

[43] M. Sakari, L. S. Ting, L. Y. Houng et al., "Urban effluent discharge into rivers; a forensic chemistry approach to evaluate the environmental deterioration," World Applied Sciences Journal, vol. 20, no. 9, pp. 1227-1235, 2012.

[44] K. A. Kvenvolden and C. K. Cooper, "Natural seepage of crude oil into the marine environment," Geo-Marine Letters, vol. 23, no. 3-4, pp. 140-146, 2003.

[45] M. Sakari, M. P. Zakaria, M. Junos et al., "Spatial distribution of petroleum hydrocarbon in sediments of major rivers from east coast of Peninsular Malaysia," Coastal Marine Science, vol. 32, pp. 1-10, 2008.

[46] T. Strother, S. Lowry, and B. Bravo, "Measurement of dispersed oil in water using an infrared analysis method," Application Note 52439, Thermo Fisher Scientific Inc, 2013.

[47] S. Buckland, Draft Sampling Protocols and Analytical Methods for Determining Petroleum Products in Soil and Water, Oil Industry Environmental Working Group, 1999.

[48] Kansas Department of Health and Environment (KDHE), Kansas Method for the Determination of Mid-Range Hydrocarbons (MRH) and High-Range Hydrocarbons (HRH), Revision 1.0, 2015.

[49] ESS Laboratory, "Total petroleum hydrocarbons (SW 846 Method 8100 modified)," SOP No: 60_8100-mod. Revision 4: 23, 2008.

[50] S. Suratman, "Distribution of total petrogenic hydrocarbon in Dungun River basin, Malaysia," Oriental Journal of Chemistry, vol. 29, no. 1, pp. 77-80, 2013.

[51] J. P. Morris, Residual diesel range organics and selected frothers in process waters from fine coal flotation [Master of Science Thesis in Mining and Minerals Engineering], Virginia Polytechnic Institute and State University, 2013.

[52] J. E. Cortes, A. Suspes, S. Roa, C. González, and H. E. Castro, "Total petroleum hydrocarbons by gas chromatography in Colombian waters and soils," American Journal of Environmental Sciences, vol. 8, no. 4, pp. 396-402, 2012.

[53] J. Ilavsky and J. Hrivnak, "Determination of petroleum hydrocarbons in water by microextraction and capillary gas chromatogarphy," Slovakia Journal of Civil Engineering, vol. 1, pp. 1317, 2004.

[54] B. Johnson, "Determining trace amounts of contaminants in water," Water Conditioning and Purification, 2016, http://www .horizontechinc.com/PDF/WCP_article_2011.pdf.

[55] D. Gallagher, "Determining Diesel and Oil Range Organics in Water Using Automated Solid Phase Extraction," Horizon Technology, Inc. AN064-100625: 1-4, 2002.

[56] W. Zhang, H. Feng, J. Chang, J. Qu, H. Xie, and L. Yu, "Heavy metal contamination in surface sediments of Yangtze River intertidal zone: an assessment from different indexes," Environmental Pollution, vol. 157, no. 5, pp. 1533-1543, 2009.

[57] M. Fingas, Ed., Handbook of Oil Spill Science and Technology, John Wiley \& Sons, Hoboken, NJ, USA, 2015. 
[58] M. K. Stenstrom, S. Fam, and G. S. Silverman, "Analytical methods for quantitative and qualitative determination of hydrocarbons and oil and grease in water and wastewater," Environmental Technology Letters, vol. 7, no. 1-12, pp. 625-636, 1986.

[59] American Water Works Association (AWWA), American Water Works Association, American Water Works Association (AWWA), Denver, Colo, USA, 1st edition, 1998.

[60] J. G. Speight, Lange's Handbook of Chemistry, McGraw-Hill, New York, NY, USA, 6th edition, 2005.

[61] S. Filho, P. J. Luz, G. R. Betemps, M. D. R. G. Silva, and E. B. Caramao, "Studies of n-alkanes in the sediments of colony Z3 (Pelotas-RS-Brazil)," Brazilian Journal of Aquatic Science and Technology, vol. 17, no. 1, pp. 27-33, 2013.

[62] O. L. G. Maioli, K. C. Rodrigues, B. A. Knoppers, and D. A. Azevedo, "Distribution and sources of aliphatic and polycyclic aromatic hydrocarbons in suspended particulate matter in water from two Brazilian estuarine systems," Continental Shelf Research, vol. 31, no. 10, pp. 1116-1127, 2011.

[63] I. J. Alinnor and M. A. Nwachukwu, "Determination of total petroleum hydrocarbon in soil and groundwater samples in some communities in Rivers State, Nigeria," Journal of Environmental Chemistry and Ecotoxicology, vol. 5, no. 11, pp. 292-297, 2013.

[64] F. Galbiati and L. Teli, Determination of Total Petroleum Hydrocarbons in Rubble and Soils by Accelerated Solvent Extraction and GC-FID, Thermo Fisher Scientific, 2015.

[65] E. V. Lau, S. Gan, and H. K. Ng, "Extraction techniques for polycyclic aromatic hydrocarbons in soils," International Journal of Analytical Chemistry, vol. 2010, Article ID 398381, 9 pages, 2010.

[66] I. J. Okop and S. C. Ekpo, "Determination of total hydrocarbon content in soil after petroleum spillage," in Proceedings of the World Congress on Engineering (WCE '12), vol. 3, London , UK, 2012.

[67] Dionex Corporation, "Extraction of total petroleum hydrocarbon contaminants (diesel and waste oil) in soils by accelerated solvent extraction (ASE)," Dionex Application Note 338, 2011.

[68] I. De Dobbeleer, F. Galbiati, and L. Teli, "Determination of total petroleum hydrocarbons in rubble and soils by accelerated solvent extraction and GC-FID," Poster Note 64829, Thermo Fisher Scientific, 2016.

[69] H. Giergielewicz-Możajska, Ł. Dąbrowski, and J. Namieśnik, "Accelerated solvent extraction (ASE) in the analysis of environmental solid samples-some aspects of theory and practice," Critical Reviews in Analytical Chemistry, vol. 31, no. 3, pp. 149165, 2001.

[70] D. A. Zemo, K. A. Synowiec, R. I. Magaw, and R. E. Mohler, "Comparison of shake and column silica gel cleanup methods for groundwater extracts to be analyzed for TPHd/DRO," Groundwater Monitoring and Remediation, vol. 33, no. 4, pp. 108-112, 2013.

[71] R. Saddler and D. Connell, "Analytical methods for the determination of total petroleum hydrocarbons in soil," in Proceedings of the 5th National Workshop on the Assessment of Site Contamination, pp. 133-150, National Environment Protection Council Service Corporation, 2003.

[72] C. M. Reddy and J. G. Quinn, "GC-MS analysis of total petroleum hydrocarbons and polycyclic aromatic hydrocarbons in seawater samples after the North Cape oil spill," Marine Pollution Bulletin, vol. 38, no. 2, pp. 126-135, 1999.
[73] R. N. Okparanma and A. M. Mouazen, "Determination of total petroleum hydrocarbon (TPH) and polycyclic aromatic hydrocarbon (PAH) in soils: a review of spectroscopic and nonspectroscopic techniques," Applied Spectroscopy Reviews, vol. 48, no. 6, pp. 458-486, 2013.

[74] M. Matthew, A comparison study of gravimetric and ultraviolet fluorescence methods for the analysis of total petroleum hydrocarbons in surface water [M.S. thesis], Northeastern University, Boston, Mass, USA, 2009.

[75] United States Environmental Protection Agency (USEPA), "Analytical method guidance for EPA method 1664a implementation and use (40 CFR part 136)," Office of Water 4303, 2000.

[76] United States Environmental Protection Agency (USEPA), "Method 1664, Revision A: n-Hexane extractable material (HEM; oil and grease) and silica gel treated n-hexane extractable material (SGTHEM; non-polar material) by extraction and gravimetry," Tech. Rep. EPA-821-R-98-002. PB99121949, 1999.

[77] United States Environmental Protection Agency (USEPA), Method 9071B: N-hexane Extractable Material (HEM) for Sludge, Sediment, and Solid Samples, Revision 2, 1998.

[78] M. S. Massoud, F. Al-Abdali, A. N. Al-Ghadban, and M. AlSarawi, "Bottom sediments of the Arabian Gulf-II. TPH and TOC contents as indicators of oil pollution and implications for the effect and fate of the Kuwait oil slick," Environmental Pollution, vol. 93, no. 3, pp. 271-284, 1996.

[79] P. C. Onianwa, "Petroleum hydrocarbon pollution of urban topsoil in Ibadan City, Nigeria," Environment International, vol. 21, no. 3, pp. 341-343, 1995.

[80] A. A. Adeniyi and J. A. Afolabi, "Determination of total petroleum hydrocarbons and heavy metals in soils within the vicinity of facilities handling refined petroleum products in Lagos metropolis," Environment International, vol. 28, no. 1-2, pp. 79-82, 2002.

[81] M. E. Essington, Soil and Water Chemistry: An Integrative Approach, CRC Press, Boca Raton, Fla, USA, 2004.

[82] M. Martl and W. Ritter, "Brings back CFC-free IR measurement for oil-in-water," ASTM Standard D7678-11, QuantaRed Technologies $\mathrm{GmbH}, 2013$, https://www.petro-online.com/.

[83] United States Environmental Protection Agency (USEPA), Method 8015D: Non-Halogenated Organics Using GC/FID. Revision 4, United States Environmental Protection Agency, Washington, DC, USA, 2003.

[84] British Colombia Ministry of Environment (BCME), "Aliphatic/aromatic separation of extractable petroleum hydrocarbons in solids or water by silica gel fractionation," in Analytical Method 7 for Contaminated Sites, Version 2.1, pp. 3-11, 2001.

[85] G. S. Douglas, K. J. McCarthy, D. T. Dahlen et al., "The use of hydrocarbon analyses for environmental assessment and remediation," Journal of Soil Contamination, vol. 1, no. 3, pp. 197-216, 1992.

[86] Z. Wang and M. F. Fingas, "Development of oil hydrocarbon fingerprinting and identification techniques," Marine Pollution Bulletin, vol. 47, no. 9-12, pp. 423-452, 2003.

[87] G. S. Frysinger, R. B. Gaines, L. Xu, and C. M. Reddy, "Resolving the unresolved complex mixture in petroleum-contaminated sediments," Environmental Science and Technology, vol. 37, no. 8, pp. 1653-1662, 2003.

[88] J. Krupcík, P. Oswald, D. Oktavec, and D. W. Armstrong, "Calibration of GC-FID and IR spectrometric methods for 
determination of high boiling petroleum hydrocarbons in environmental samples," Water, Air, and Soil Pollution, vol. 153, no. 1-4, pp. 329-341, 2004.

[89] The International Tanker Owners Pollution Federation Limited (ITOPFL), "Sampling and monitoring of marine oil spills," Technical Information Paper 14, 2012.

[90] Quick Results on Site (QROS), Hydrocarbon Analysis with QED ${ }^{\circledR}, 2012$, http://www.qros.co.uk/hydrocarbon_analysis.html.

[91] P. W. Sammarco, S. R. Kolian, R. A. Warby, J. L. Bouldin, W. A. Subra, and S. A. Porter, "Distribution and concentrations of petroleum hydrocarbons associated with the BP/Deepwater Horizon Oil Spill, Gulf of 108 Mexico," Marine Pollution Bulletin, vol. 73, pp. 129-143, 2013.

[92] L. A. Soto, A. V. Botello, S. Licea-Durán, M. L. LizárragaPartida, and A. Yáñez-Arancibia, "The environmental legacy of the Ixtoc-I oil spill in Campeche Sound, southwestern Gulf of Mexico," Frontiers in Marine Science, vol. 1, no. 57, pp. 1-9, 2014.

[93] P. D. Boehm and D. L. Fiest, "Subsurface distributions of petroleum from an offshore well blowout. The Ixtoc I blowout, Bay of Campeche," Environmental Science and Technology, vol. 16, no. 2, pp. 67-74, 1982.

[94] D. Griffin, N. Black, and C. Devine, "5 years after the Gulf oil spill: what we do (and don't) know. 2010 Gulf Oil Spills," CNN, International Edition. Updated 1707 GMT (0107 HKT), 2015, http://edition.cnn.com/2015/04/14/us/gulf-oil-spill-unknowns/.

[95] J. A. Sciortino and R. Ravikumar, Fishery Harbour Manual on the Prevention of Pollution, BOBP/MAG/22, Hay of Bengal Programme, Madras, India, 1990.

[96] G. O. Adewuyi, O. T. Etchie, and O. T. Ademoyegun, "Determination of total petroleum hydrocarbons and heavy metals in surface water and sediment of Ubeji River, Warri, Nigeria," Bioremediation, Biodiversity and Bioavailability, vol. 5, no. 1, pp. 46-51, 2011.

[97] S. L. Mohebbi-Nozar, M. P. Zakaria, W. R. Ismail et al., “Total petroleum hydrocarbons in sediments from the coastline and mangroves of the northern Persian Gulf," Marine Pollution Bulletin, vol. 95, no. 1, pp. 407-411, 2015.

[98] X. Peng, G. Zhang, B. Mai, J. Hu, K. Li, and Z. Wang, "Tracing anthropogenic contamination in the Pearl River estuarine and marine environment of South China Sea using sterols and other organic molecular markers," Marine Pollution Bulletin, vol. 50, no. 8, pp. 856-865, 2005.

[99] G. Wattayakorn and S. Rungsupa, "Petroelum hydrocarbon residues in the marine environment of Koh Sichang-Sriracha, Thailand," Coastal Marine Science, vol. 35, no. 1, pp. 122-128, 2012.

[100] United Nations Environment Programme (UNEP), "Determination of petroleum hydrocarbons in sediments," Reference Methods for Marine Pollution Studies, vol. 20, pp. 33-75, 1992.

[101] I. Bouloubassi, J. Fillaux, and A. Saliot, "Hydrocarbons in surface sediments from there Changjiang (Yangtze River) Estuary, East China Sea," Marine Pollution Bulletin, vol. 42, no. 12, pp. 1335-1346, 2001.

[102] J. Li, B. Zhou, J. Shao, Q. Yang, Y. Liu, and W. Cai, "Influence of the presence of heavy metals and surface-active compounds on the sorption of bisphenol A to sediment," Chemosphere, vol. 68, no. 7, pp. 1298-1303, 2007.

[103] Q. Li, Z. Wu, B. Chu, N. Zhang, S. Cai, and J. Fang, "Heavy metals in coastal wetland sediments of the Pearl River Estuary, China," Environmental Pollution, vol. 149, no. 2, pp. 158-164, 2007.
[104] J. M. Guerra-García and J. C. García-Gómez, "Assessing pollution levels in sediments of a harbour with two opposing entrances. Environmental implications," Journal of Environmental Management, vol. 77, no. 1, pp. 1-11, 2005.

[105] C. H. Vane, S. R. Chenery, I. Harrison, A. W. Kim, V. Moss-Hayes, and D. G. Jones, "Chemical signatures of the Anthropocene in the Clyde estuary, UK: sediment-hosted $\mathrm{Pb}, 207 / 206 \mathrm{~Pb}$, total petroleum hydrocarbon, polyaromatic hydrocarbon and polychlorinated biphenyl pollution records," Philosophical Transactions of the Royal Society A: Mathematical, Physical and Engineering Sciences, vol. 369, no. 1938, pp. 10851111, 2011.

[106] S. Greason, Field Screening Petroleum Hydrocarbons Using Ultraviolet Fluorescence Technology, Sitelab Corporation, West Newbury, Mass, USA, 2009.

[107] Environment Agency (EA), EA (UK Environment Agency) Framework for the Use of Rapid Measurement Techniques (RMT) in the Risk Management of Land Contamination, Environment Agency, Bristol, UK, 2009.

[108] R. Becker, M. Koch, S. Wachholz, and T. Win, "Quantification of total petrol hydrocarbons (TPH) in soil by IR-spectrometry and gas chromatography-conclusions from three proficiency testing rounds," Accreditation and Quality Assurance, vol. 7, no. 7, pp. 286-289, 2002.

[109] Y. Li, Y. Zhao, S. Peng, Q. Zhou, and L. Q. Ma, “Temporal and spatial trends of total petroleum hydrocarbons in the seawater of Bohai Bay, China from 1996 to 2005," Marine Pollution Bulletin, vol. 60, no. 2, pp. 238-243, 2010.

[110] G. O. Adewuyi and R. A. Olowu, "Assessment of oil and grease, total petroleum hydrocarbons and some heavy metals in surface and groundwater within the vicinity of NNPC Oil Depot in Apata, Ibadan metropolis, Nigeria," International Journal of Research and Revies in Applied Sciences, vol. 13, no. 1, pp. 166174, 2012.

[111] I. J. Alinnor, C. E. Ogukwe, and N. C. Nwagbo, "Characteristic level of total petroleum hydrocarbon in soil and groundwater of oil impacted area in the Niger Delta region, Nigeria," Journal of Environment and Earth Science, vol. 4, no. 23, pp. 188-194, 2014.

[112] A. R. Abdullah, W. C. Woon, and R. A. Bakar, "Distribution of oil and grease and petroleum hydrocarbons in the Straits of Johor, Peninsular Malaysia," Bulletin of Environmental Contamination and Toxicology, vol. 57, no. 1, pp. 155-162, 1996.

[113] A. A. Maktoof, B. Y. ALKhafaji, and Z. Z. Al-Janabi, "Evaluation of total hydrocarbons levels and traces metals in water and sediment from main outfall drain in Al-Nassiriya City/Southern Iraq," Natural Resources, vol. 5, no. 13, pp. 795-803, 2014.

[114] S. Suratman, N. M. Tahir, and M. T. Latif, "A Preliminary study of total petrogenic hydrocarbon distribution in setiu wetland, southerzn South China Sea (Malaysia)," Bulletin of Environmental Contamination and Toxicology, vol. 88, no. 5, pp. 755-758, 2012.

[115] Shemen Oil and Gas Resources Israel (SOGRLI), Final Report: Yam-3 Environmental Monitoring Post-Drill Survey Report, CSA Ocean Sciences, Stuart, Fla, USA, 2014.

[116] M. I. El Samra, H. I. Emara, and F. Shunbo, "Dissolved petroleum hydrocarbon in the northwestern Arabian Gulf," Marine Pollution Bulletin, vol. 17, no. 2, pp. 65-68, 1986.

[117] J. T. Tanacredi, "Petroleum hydrocarbons from effluents: detection in marine environment," Journal of the Water Pollution Control Federation, vol. 49, no. 2, pp. 216-226, 1977.

[118] D. Ţigănuș, V. Coatu, L. Lazăr, and A. Oros, "Present level of petroleum hydrocarbons in seawater associated with offshore 
exploration activities from the Romanian Black Sea sector," Cercetări Marine, vol. 46, pp. 98-108, 2016.

[119] A. Korshenko, I. Matveichuk, T. Plotnikova, and V. Luchkov, Marine Water Pollution, Annual Report 2003, Hydrometeoizdat, St. Petersburg, Russia, 2005 (Russian).

[120] A. Korshenko, I. Matveichuk, T. Plotnikova, and V. Luchkov, "Marine waters quality on hydrochemical parameters," Annual Report, Hydrometeoizdat, St. Petersburg, Russia, 2003 (Russian).

[121] R. A. Van Dam, C. Camilleri, and C. Turley, "Preliminary assessment of petroleum hydrocarbons in water and sediment at Yellow Water, Kakadu National Park," Internal Report 283, Department of the Environment and Energy, Parkes, Australia, 1998.

[122] N. Mzoughi, M. Dachraoui, and J.-P. Villeneuve, "Evaluation of aromatic hydrocarbons by spectrofluorometry in marine sediments and biological matrix: what reference should be considered?" Comptes Rendus Chimie, vol. 8, no. 1, pp. 97-102, 2005.

[123] A. B. Garali, M. Ouakad, and M. Gueddari, "Contamination of superficial sediments by heavy metals and iron in the Bizerte lagoon, northern Tunisia," Arabian Journal of Geosciences, vol. 3, no. 3, pp. 295-306, 2010.

[124] M. S. Massoud, F. Al-Abdali, and A. N. Al-Ghadban, "The status of oil pollution in the Arabian Gulf by the end of 1993," Environment International, vol. 24, no. 1-2, pp. 11-22, 1998.

[125] R. Zhou, X. Qin, S. Peng, and S. Deng, "Total petroleum hydrocarbons and heavy metals in the surface sediments of Bohai Bay, China: long-term variations in pollution status and adverse biological risk," Marine Pollution Bulletin, vol. 83, no. 1, pp. 290-297, 2014.

[126] G. M. Tehrani, R. Hashim, A. H. Sulaiman et al., "Distribution of total petroleum hydrocarbons and polycyclic aromatic hydrocarbons in musa bay sediments (Northwest of the Persian Gulf)," Environment Protection Engineering, vol. 39, no. 1, pp. 115-128, 2013.

[127] G. H. Monazami Tehrani, H. Rosli, A. H. Sulaiman et al., "Petroleum hydrocarbon assessment in the wastewaters of petrochemical special economic zone and sediment benchmark calculation of the coastal area-northwest of the Persian Gulf," Iranian Journal of Fisheries Sciences, vol. 13, no. 1, pp. 119-134, 2014.

[128] S. A. Mohd Ali, R. Tair, S. Z. Yang, and M. Mohd Ali, "Petroleum hydrocarbon in surface sediment from coastal area of Putatan and Papar, Sabah," Malaysian Journal of Analytical Sciences, vol. 17, no. 2, pp. 286-290, 2013.

[129] S. W. Fowler, J. W. Readman, B. Oregioni, J.-P. Villeneuve, and K. McKay, "Petroleum hydrocarbons and trace metals in nearshore Gulf sediments and biota before and after the 1991 war: an assessment of temporal and spatial trends," Marine Pollution Bulletin, vol. 27, pp. 171-182, 1993.

[130] C. H. Vane, I. Harrison, A. W. Kim, V. Moss-Hayes, B. P. Vickers, and B. P. Horton, "Status of organic pollutants in surface sediments of Barnegat Bay-Little Egg Harbor Estuary, New Jersey, USA," Marine Pollution Bulletin, vol. 56, no. 10, pp. 1802-1808, 2008.

[131] L. P. Rozas, T. J. Minello, and C. B. Henry, "An assessment of potential oil spill damage to salt marsh habitats and fishery resources in Galveston Bay, Texas," Marine Pollution Bulletin, vol. 40, no. 12, pp. 1148-1160, 2000.

[132] P. H. Santschi, B. J. Presley, T. L. Wade, B. Garcia-Romero, and M. Baskaran, "Historical contamination of PAHs, PCBs, DDTs, and heavy metals in Mississippi River Delta, Galveston Bay and Tampa Bay sediment cores," Marine Environmental Research, vol. 52, no. 1, pp. 51-79, 2001.

[133] J. J. Celino, O. M. C. de Oliveira, G. M. Hadlich, de. Souza, A. F. Queiroz, and K. S. Garcia, "Assessment of contamination by trace metals and petroleum hydrocarbons in sediments from the tropical estuary of Todos os Santos Bay, Brazil," Revista Brasileira de Geociências, vol. 38, no. 4, pp. 753-760, 2008.

[134] J. B. R. Agard, M. Boodoosingh, and J. Gobin, "Petroleum residues in surficial sediments from the Gulf of Paris, Trinidad," Marine Pollution Bulletin, vol. 19, no. 5, pp. 231-233, 1988. 

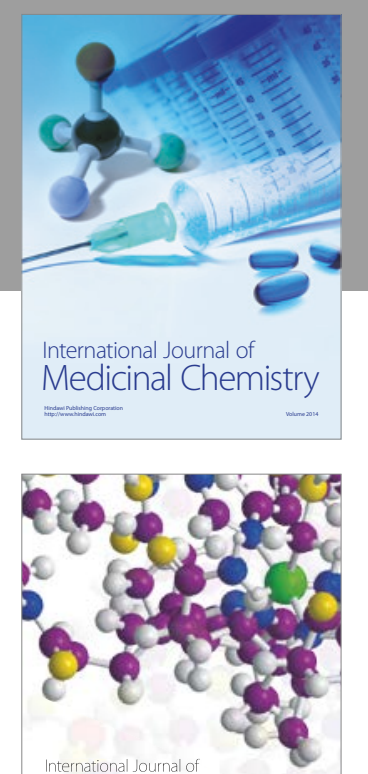

Carbohydrate Chemistry

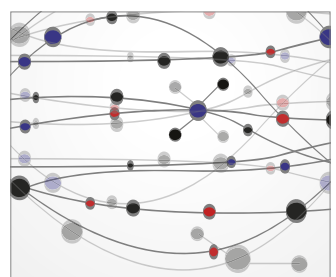

The Scientific World Journal
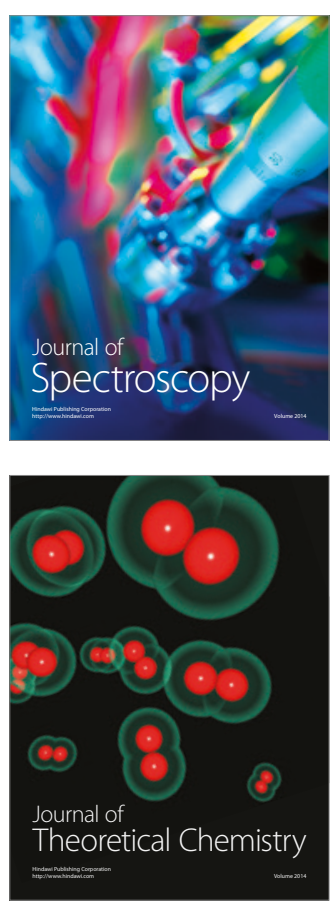
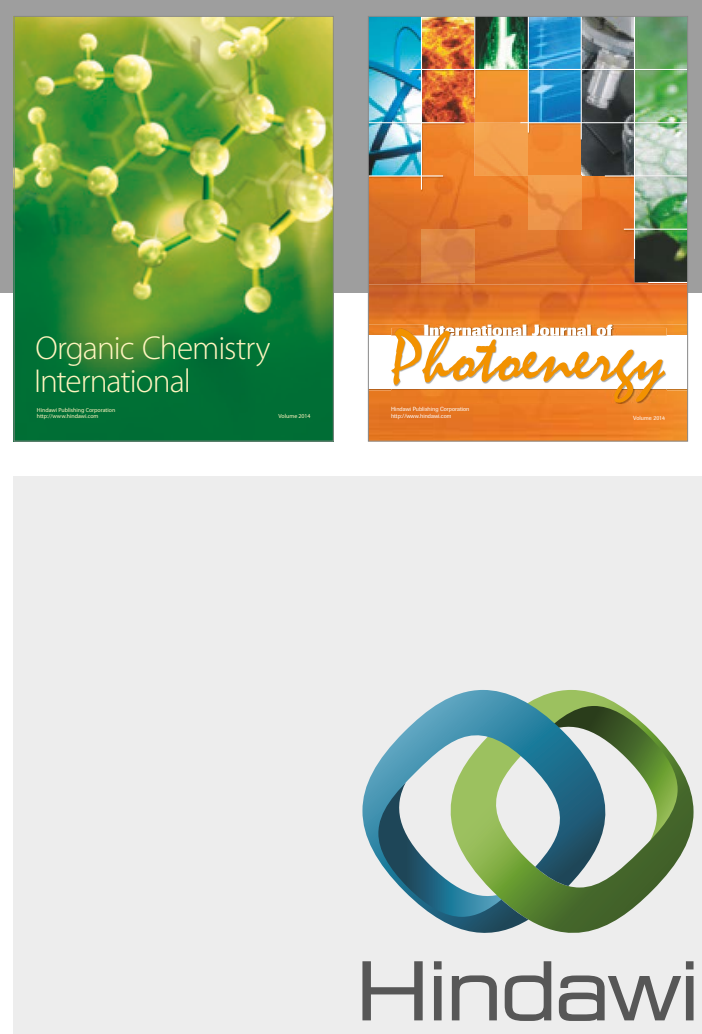

Submit your manuscripts at

https://www.hindawi.com

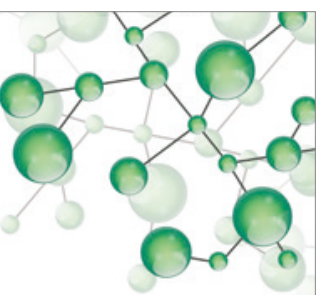

International Journal of

Inorganic Chemistry

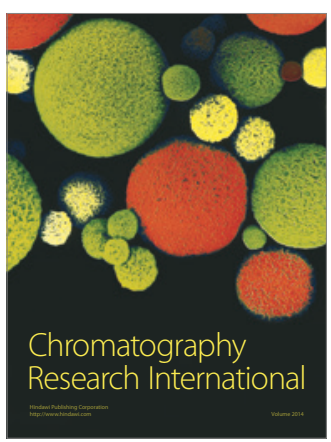

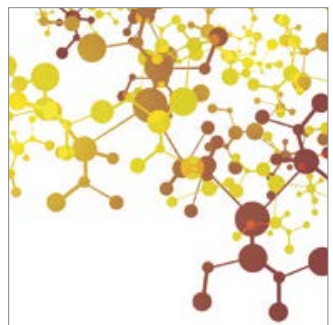

Applied Chemistry
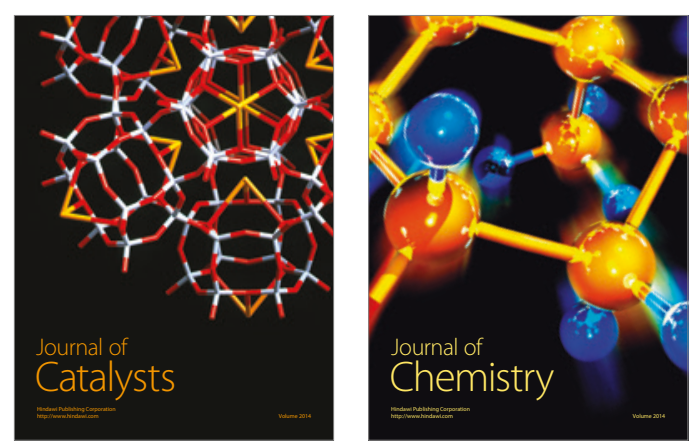
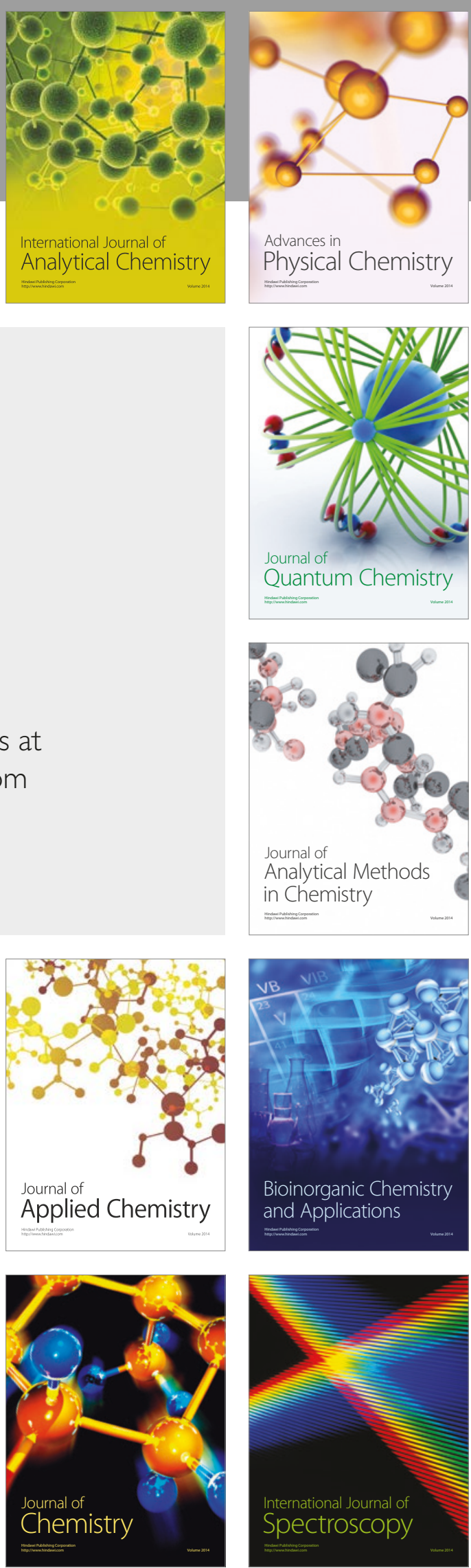